\title{
Teaching strategies and techniques in mixed-ability classes
}

\author{
Bartłomiej Wróbłewski, Marie Majerová
}

\begin{abstract}
In this article, the authors review their day-to-day experience with teaching mixedability classes at an institution of higher learning. In the first part, they analyse the typical composition of the student population in a class, using the specific situation of the courses on "English for Health Care Professionals". Students are further characterized in terms of their initial language competence, age, aptitude and motivation. In the second part, the authors present several practical activities they use with the general objective to maximize involvement and language acquisition of all individual students. The practical experience is scrutinized in relation to recent teaching and learning methodologies. The authors discuss strategies such as task and material variation, collaborative learning, individualization, and changes to classroom arrangement. In conclusion, they recommend a mix of varied activities to be tailored with respect to individual heterogeneous groups.
\end{abstract}

Key words: mixed-ability class, motivation, teaching strategies, collaborative learning, task differentiation, classroom arrangement

\begin{abstract}
Abstrakt: V příspěvku autoři hodnotí svoji každodenní zkušenost s výukou heterogenních studijních skupin na vysoké škole. V první části autoři popisují typické složení studijní skupiny kurzů "Angličtiny pro zdravotníky" a charakterizují studenty z hlediska vstupní jazykové competence a věkového složení. Pozornost je věnována problematice jazykových vloh a motivace. V druhé části jsou prezentovány praktické výukové komponenty používané s cílem maximalizovat aktivní zapojení a jazykový růst každého jednotlivého studenta. Praktická zkušenost je reflektována ve vztahu k aktuálním výukovým metodám. Diskutované strategie zahrnují adaptace a diferenciace výukových materiálů a úkolů, vybrané formy kooperativního učení, individualizace výuky a změny v prostorovém uspořádání tříd. Závěrem autoři doporučují kombinovat úspěšné výukové komponenty s ohledem na konkrétní heterogenní skupiny.
\end{abstract}

Klíčová slova: heterogenní třída, motivace, výukové strategie, kooperativní učení, variabilita úkolů, uspořádání třídy

\section{Introduction}

Dealing with students with different levels of language competence seems to be a common challenge in teaching. The aim of the present article is to tackle the issue from the position of language teachers who, due to the study programme design, always instruct student groups of mixed abilities. Students will be characterized in terms of their age, study background, motivation and aptitude. Furthermore, teaching strategies proposed in current literature will be discussed in relation to real-life activities and arrangements implemented in the teaching prac- 
tice. In conclusion, the authors recommend selecting a mix of activities in order to maximize involvement and language acquisition of all students in the given group.

\section{The English for Health Care Professionals course}

Based at the University of West Bohemia in Pilsen (Czech Republic), the authors have been teaching English to students of the Faculty of Health Care Studies (FZS). The subject called "English for Health Care Professionals" is a "B" category course for the students, i.e. a "compulsory-elective" one. This categorization means that the candidates have to register for a foreign language as part of the study programme, presently having a choice between English (opted for by about 90\%) and German. English for Health Care Professionals is taught in two semesters; each course (coded AZ1 and AZ2) is completed by a written credit test. Since the students have different specializations (physiotherapists, occupational therapists, lab technicians, radiation technicians, paramedics, orthotists/prosthetists, hygienists), due to the schedule requirements they are streamed into study groups (average size of 16-18) on the basis of their specialization rather than actual language competence.

\section{Student characteristics}

University-wide entrance language competence is assessed during the enrolment procedure when the students take the adaptive online Oxford Placement Test. (The full methodology of the test is described at www.oxfordenglishtesting.com.) As a result, students get two scores for Use of English and Listening and a combined, overall score (0-100) that corresponds with the appropriate CEFR level (A0-C2). The conversion values for corresponding CEFR levels are detailed in Table 1.

Tab. 1: Overall Oxford Placement Test score / CEFR level conversion table

\begin{tabular}{|c|c|}
\hline A1 & $1-20$ \\
\hline A2 & $21-40$ \\
\hline B1 & $41-60$ \\
\hline B2 & $61-80$ \\
\hline C1 & $81-100$ \\
\hline C2 & $>101$ \\
\hline
\end{tabular}

Approximately 250 FZS students take the test each year. The average scores achieved by FZS students in recent years are detailed in Table 2.

The statistical results give a convenient average level oscillating around the score of 40, i.e. at the lower margin of B1 according to CEFR. The micro-composition of the classes typically provides a different picture. The table below contains the data 
Tab. 2: Average Oxford Placement Test scores of FZS students between 2012 and 2018

\begin{tabular}{|c|c|c|c|c|c|c|}
\hline 2012 & 2013 & 2014 & 2015 & 2016 & 2017 & 2018 \\
\hline 23.3 & 38.5 & 41.73 & 46.19 & 42.81 & 38.99 & 44.32 \\
\hline A2 & A2 & B1 & B1 & B1 & A2 & B1 \\
\hline
\end{tabular}

based on the midterm test taken by the students in the sixth week of their first semester in the last academic year (2018/2019). The test itself is strongly focused on vocabulary items introduced and on their use in context, i.e. use of English skills. Since the students have only had a limited amount of language instruction, it can be assumed that their entrance level plays a significant role in the test scores. The results used here represent the percentage of correct answers in the test; they do not constitute any CEFR value, but can be used reliably to illustrate the language competence differences and their proportion within the classes.

Tab. 3: Results of Midterm test 2018/2019

\begin{tabular}{|c|c|c|c|c|c|c|c|c|c|}
\hline Class No. & $\begin{array}{c}\text { No. of } \\
\text { students }\end{array}$ & $\begin{array}{c}\text { Average } \\
\text { score } \mathbf{\%}\end{array}$ & $\begin{array}{c}\text { Itemized } \\
\text { score } \\
\mathbf{0 - 2 0 \%}\end{array}$ & $\begin{array}{c}\text { Itemized } \\
\text { score } \\
\mathbf{2 1 - 4 0 \%}\end{array}$ & $\begin{array}{c}\text { Itemized } \\
\text { score } \\
\mathbf{4 1 - 6 0 \%}\end{array}$ & $\begin{array}{c}\text { Itemized } \\
\text { score } \\
\mathbf{6 1 - 8 0 \%}\end{array}$ & $\begin{array}{c}\text { Itemized } \\
\text { score } \\
\mathbf{8 1 - 1 0 0 \%}\end{array}$ & $\begin{array}{c}\text { Lowest } \\
\text { score } \\
\text { in group }\end{array}$ & $\begin{array}{c}\text { Highest } \\
\text { score } \\
\text { in group }\end{array}$ \\
\hline 1 & 14 & 60.0 & 0 & 4 & 2 & 5 & 3 & 22 & 100 \\
\hline 2 & 15 & 53.6 & 0 & 4 & 7 & 3 & 1 & 31 & 92 \\
\hline 3 & 11 & 57.4 & 0 & 2 & 5 & 3 & 1 & 35 & 91 \\
\hline 4 & 16 & 73.1 & 1 & 1 & 1 & 6 & 7 & 20 & 91 \\
\hline 5 & 15 & 78.3 & 0 & 1 & 1 & 6 & 7 & 35 & 97 \\
\hline 6 & 14 & 62.3 & 0 & 1 & 5 & 6 & 2 & 34 & 81 \\
\hline 7 & 12 & 69.6 & 0 & 1 & 3 & 3 & 5 & 36 & 97 \\
\hline 8 & 14 & 69.9 & 0 & 0 & 5 & 5 & 4 & 45 & 96 \\
\hline 9 & 9 & 50.0 & 0 & 2 & 2 & 5 & 0 & 22 & 77 \\
\hline 10 & 15 & 60.3 & 0 & 5 & 1 & 5 & 4 & 25 & 95 \\
\hline 11 & 11 & 78.1 & 0 & 1 & 1 & 2 & 7 & 29 & 98 \\
\hline 12 & 12 & 74.4 & 0 & 1 & 1 & 4 & 6 & 37 & 88 \\
\hline 13 & 10 & 80.5 & 0 & 0 & 0 & 4 & 6 & 64 & 96 \\
\hline 14 & 17 & 67.5 & 0 & 2 & 3 & 8 & 4 & 26 & 92 \\
\hline 15 & 15 & 69.9 & 0 & 1 & 3 & 5 & 6 & 24 & 99 \\
\hline 16 & 12 & 73.6 & 0 & 1 & 1 & 4 & 6 & 28 & 100 \\
\hline 17 & 13 & 72.2 & 0 & 1 & 1 & 6 & 5 & 33 & 94 \\
\hline 18 & 15 & 78.5 & 0 & 0 & 3 & 3 & 6 & 53 & 96 \\
\hline
\end{tabular}

The total number of students who took the midterm test was 240 . There were 28 students with a score of 40 or lower who can be classified as weak $(11.6 \%)$ and 80 students with a score of 80 and above who can be classified as strong $(33.3 \%)$. It can be generalized that there are about five very proficient students and two or three quite weak ones in each mixed-ability group. Student groups are rather homogeneous in terms of age (19-20); most of the students are in their first year 
of university studies after completing their secondary education with the "Maturita" leaving exam. There seems to be a strong correlation between the type of secondary school and the level of language competence achieved: students coming from general grammar schools ("Gymnasium") tend to be stronger compared to students with a technical/vocational secondary school background. Nevertheless, due to final test standardisation, all the students at FZS are obliged to take the same test at the end of each semester. Therefore, if students' proficiency level is lower than required, their successful performance depends strongly on their self-study. For a majority of the students, it is their secondary school experience with foreign languages that determines their present competence, and also their motivation, aptitude and expectations.

Drawing on Harmer's (2015) characteristics, students manifest certain traits typical for adolescent learners as well as those typical for adult ones. Teenage students are in fact the best language learners (Ur 1996) thanks to the stage of brain development and its plasticity, capability of abstract thought and memory capacity. For adult learners, acquiring a new language is a conscious exercise of intellect; these students have certain expectations about the learning process and frequently also their own set patterns of learning. While disruptive behaviour is rare, to engage students' full attention may be a challenge. The teacher's first task is to stimulate the students' engagement with material that is relevant and involving; that relates to their own interests, thoughts and experience (Harmer 2015). Also, a good teacher sets high expectations for all students; it is well known that students generally give teachers as much or as little as is expected of them. In this context, McKeachie highlights the importance of students' feeling that the teacher cares about both their learning and them as individuals, and the value of getting students to participate in discussion (McKeachie, $(1951,1999)$ in Weimer (2008)).

\section{Learning strategies and motivation}

It is commonly agreed that students differ in their aptitude for language acquisition. Nevertheless, it is less clear what such an aptitude means and how it can be assessed. Harmer (2015) claims that standard aptitude tests can only measure general intellectual ability, favouring analytic types of students. According to Multiple Intelligences Theory, introduced by Gardner (1983), humans do not possess a single intelligence, but a range of intelligences (mathematical, special, linguistic, etc.). Daniel Goleman (1996) has added emotional intelligence. All students will have a unique combination of talents and abilities, and they should be viewed and valued from that perspective. Another concept that significantly influences results in language acquisition is the notion of locus of control (Findley \& Coper, 1983). As further elaborated by Williams \& Burden (1997), learners can be divided into "internalisers", i.e. those who make things happen, and "externalisers", i.e. those to 
whom things happen. In other words, some students trust in their own ability and effort, while others attribute their study results to the level of task difficulty, and also to their own good luck. The research (Findley \& Cooper (1993), in Williams \& Burden (1997)) suggests that learners who feel in control of their learning process seem to achieve better results.

Motivation pays a crucial role in the process of learning. Williams \& Burden (1997) claim that language, after all, is a part of one's identity and is used to convey this identity to other people. Motivation, i.e. "a state of cognitive and emotional arousal, which leads to a conscious decision to act, and which gives rise to a period of sustained intellectual and/or physical effort in order to attain a previously set goal or goals" (Williams \& Burden $(1997,120)$, can be influenced by a number of internal and external factors. The internal factors include the learner's interest in the activity, the perceived value of the activity, his/her sense of control and concept of self, his/her attitudes to the learning in general, to the target language and, additionally, to the target language community and culture, and, finally, his/her developmental age and stage. The external factors incorporate significant others (family, teachers, peers), the nature of interaction with significant others, the learning environment, and also the broader context of learning, e.g. the whole family, cultural and educational background.

Ultimately, teachers need to arouse students' curiosity and propose tasks that are appropriate in terms of difficulty, so that all learners have an opportunity to experience the feeling of success. Consequently, the same learning task will not be appropriate for all students, and differentiation is needed, as further discussed in Section 4 . At the same time, the course we teach follows a relatively rigid syllabus with its main focus on new vocabulary (medical terminology, the human body, drugs, diseases, etc.). The teaching approach is as follows: all students are supposed to master certain "core" vocabulary and grammar, which is clearly determined by the textbook and the acquisition of which is assessed through the final credit test. Stronger students are offered "extensions", i.e. additional vocabulary items, less frequently used grammar structures, etc., for example in the form of differentiated work sheets. In an ideal world, each student would benefit from a different mix of learning tasks and activities. That, of course, is impossible to achieve in this context.

Despite the fact that large classes of mixed-level students and limited class time make individually tailored teaching impossible, it is nevertheless possible to adapt some methods and materials that should provoke students' individual involvement and motivation by making alterations which take into account their different levels. Arousing and maintaining student interest is crucial, so the specific tasks should trigger student initiative, promote collaboration and provide the experience of success, which can be attained by game-like activities, open-ended ques- 
tions, visual materials, etc. (Ur, 2012). All that hopefully helps students achieve better personal results and enjoy the process of learning at the same time. The following section discusses some of these issues and gives examples of useful adaptations for dealing with groups having mixes abilities.

\section{Managing mixed-ability classes}

\subsection{Whole-class teaching}

Facing a heterogeneous group, the teacher soon discovers that whole-class teaching is not ideal. Harmer (2015) observes that teaching and learning are often regarded as "whole-class grouping" - a process in which a teacher stands in front of students who sit in orderly rows and mostly listen to what they are told. He claims that this type of interaction enables teachers to stay in control and strengthens a sense of belonging within a group. However, he also lists a few disadvantages that seem of crucial importance when dealing with mixed-level proficiency within a class. First of all, he points out that students' speaking time is significantly reduced due to the greater number of people taking part in a conversation. Moreover, as Harmer puts it, "it favours the group rather than the individual" (p. 178). This means that everyone has to do the same thing within the same amount of time, which might be quite problematic with mixed-ability classes. Finally, Scrivener (2012) states that stronger students tend to dominate and deprive weaker students of the possibility to fully participate. Nevertheless, we found whole-class teaching beneficial in certain stages of the teaching process, specifically in introducing a new theme and also in the final, review stages of individual or group activities.

\subsection{Pairing and grouping}

Since whole-class teaching is not be the most effective approach when dealing with mixed-ability classes, deliberate grouping and pairing seem to be of the utmost importance. Understandably, many teachers often assign people who sit close to each other to collaborate. Even though this saves time during the lesson, variety in the groupings makes students more involved in a task and exposes them to different accents and opinions. As Prodromou and Clandfield (2007) believe, the range of variation is considered crucial when it comes to grouping or pairing students in mixed-ability classes. Not only does deliberate diverse grouping or pairing prevent boredom but also allows teachers to, in some measure, influence the composition of a group or a pair.

To deal with differences in language proficiency within a classroom, many techniques may be implemented. One of these, described by Prodromou and Clandfield (2007) as "collaborative work", involves weaker and stronger students being 
paired so that the weaker one is supported. However, as Scrivener (2012) notes, even though weaker students may improve their language skills more efficiently, the technique used too often may unintentionally stress the differences between students or discourage stronger ones due to the lack of challenge. In practice, when provided with plenty of collaborative tasks which constantly emphasise the gap in proficiency levels, FZS students' willingness to participate dropped considerably. For these reasons, "collaborative work" should not be overused. Another technique mentioned by Prodromou and Clandfield (2007) is using "a balance of students in each group", which can be done through deliberate frequent changes in grouping that are monitored by the teacher. When implementing the variations, which usually involves standing up and moving around the classroom, students may sometimes express reluctance. So as to overcome this, teachers may apply ideas to make grouping an enjoyable activity. Scrivener (2012) lists many interesting ways to put students in pairs and groups; unfortunately, many of them do not allow teachers to control the outcome, which seems to be of significant importance when working with mixed-ability classes. He mentions, however, that monitored matching activities can be used to manipulate grouping or pairing. These are done when a teacher who is completely aware of what they give to whom distributes pieces of a task to be matched. Therefore, when pieces are not allocated randomly, the composition of groups is chosen according to the teacher's needs. Moreover, if done discreetly, students may not even be aware of the fact that the activity has been manipulated.

To illustrate, the example below presents an activity that is utilised to pair up students who have been familiarised with vocabulary concerning medical professions. The table below is cut into 16 rectangles which are then deliberately distributed among students. This monitored matching activity ensures vocabulary revision, which is not the main purpose but an additional advantage, and puts the students into pairs for a succeeding activity without them even realising that the choice of pairs is not completely random. By trying to find a rectangle that completes their sentences, the students focus on the matching activity and are not aware that they are paired purposefully. 


\begin{tabular}{|c|c|}
\hline $\begin{array}{l}\text { 1) A paediatrician ... } \\
\text { 2) ... medicines to give to medical staff or } \\
\text { patients. }\end{array}$ & $\begin{array}{l}\text { 1) ... treats children. } \\
\text { 2) A pharmacist prepares ... }\end{array}$ \\
\hline $\begin{array}{l}\text { 1) A paediatrician } \ldots \\
\text { 2) ... supports surgeons in the operating theatre. }\end{array}$ & $\begin{array}{l}\text { 1) ... treats children. } \\
\text { 2) A scrub nurse ... }\end{array}$ \\
\hline $\begin{array}{l}\text { 1) A radiologist ... } \\
\text { 2) ... responds to emergencies and gives first } \\
\text { aid. }\end{array}$ & $\begin{array}{l}\text { 1) ... takes x-rays and other images. } \\
\text { 2) A paramedic ... }\end{array}$ \\
\hline $\begin{array}{l}\text { 1) A radiologist ... } \\
\text { 2) ... with pregnant women and their unborn } \\
\text { babies. }\end{array}$ & $\begin{array}{l}\text { 1) ... takes x-rays and other images. } \\
\text { 2) An obstetrician is concerned ... }\end{array}$ \\
\hline $\begin{array}{l}\text { 1) A lab technician ... } \\
\text { 2) ... attends births and delivers babies. }\end{array}$ & $\begin{array}{l}\text { 1) ... examines samples and tissues under } \\
\text { a microscope. } \\
\text { 2) A midwife ... }\end{array}$ \\
\hline $\begin{array}{l}\text { 1) A lab technician ... } \\
\text { 2) ... performs operations. }\end{array}$ & $\begin{array}{l}\text { 1) ... examines samples and tissues under } \\
\text { a microscope. } \\
\text { 2) A surgeon ... }\end{array}$ \\
\hline $\begin{array}{l}\text { 1) A cardiologist ... } \\
\text { 2) ... moves furniture and patients around the } \\
\text { hospital. }\end{array}$ & $\begin{array}{l}\text { 1) ... deals with heart problems. } \\
\text { 2) A porter ... }\end{array}$ \\
\hline $\begin{array}{l}\text { 1) A cardiologist ... } \\
\text { 2) ... puts patients to sleep before operations. }\end{array}$ & $\begin{array}{l}\text { 1) ... deals with heart problems. } \\
\text { 2) An anaesthetist ... }\end{array}$ \\
\hline
\end{tabular}

One may argue that even though a class is divided into small groups or pairs, weaker students may still be dominated by those with better language proficiency. Fortunately, this can be avoided, to some extent, by allocating roles within each group. This technique is mentioned by Scrivener (2012), who calls it "character role-cards". Depending on the topic students discuss, the roles may differ; it is very important, however, that each student is provided with clear instructions so that they know exactly what their function is. In this kind of activity, the roles may be known by all group members, or may be kept secret. Thus, students may be given a piece of paper with a detailed description of a task. For example: You're a complainer. Whenever somebody has an idea, be sceptical about it. Try to give as many drawbacks as possible. Find a counter-argument for every argument. Or: Make sure that everyone says at least 5 sentences. Act naturally; don't let other students know what your role is. To make a discussion even more engaging, an additional element can be added, at least sometimes. Group members are instructed to identify the roles of other members, as the discussion proceeds. By trying to discover them, when still talking about a given subject, students tend to shift their focus onto a task which appears to be less stressful than a standard speaking activity. This additional task - to discover who has what role - makes the discussion more interesting and enjoyable for the participants.

A practical illustration of such a character role-cards discussion is presented below. The main subject of the discussion is "conventional and alternative methods 
of treatment". The students are divided into groups of three and each group is given a piece of paper with the following instructions:

\section{In groups of three, answer the following questions:}

- What's the difference between conventional and alternative therapies?

- Should cannabis for medical purposes be legal and funded by health insurance companies? Why? Why not?

- Suggest possible alternative treatments for the following people:

- a woman who suffers from hay fever, but after getting pregnant must discontinue using antihistamines,

- an elderly man who suffers from chronic lower back pain,

- a middle-aged businessman who suffers from persistent insomnia.

Before the discussion starts, each of the three students is individually allocated a specific role which aims at encouraging spontaneous speaking by changing the focus from speaking practice into a game-like activity. The three role-cards provide the students with the following tasks:

1. Make sure that everyone says at least 5 sentences. Act naturally; don't let other students know what your role is.

2. Use the phrase: "You have a point there, but ..." at least 5 times. Act naturally; don't let other students know what your role is.

3. You cannot use the words "yes" or "no". Act naturally; don't let other students know what your role is.

The last instruction is often highly demanding and requires rather good language proficiency; therefore, it should be given to the strongest students. When allocated properly, the additional instructions force all the students to participate in the conversation due to different tasks they need to fulfil. As a result, the situation when weaker students do not take part in group conversations is less frequent; also, the majority of students find acting highly enjoyable.

Another proven cooperative technique is the three-phase dialogue, also known as think/pair/share (Sieglová 2019). Students first work on a task individually, then form pairs and discuss and compare their solutions, and, in the last phase, they discuss the most suitable proposals in larger groups. In the activity described below, each student gets one copy of the admission dialogue. There are two versions of the task: one with a choice of replacement answers to choose from (for weaker students); one without any such choice, where the students need to propose their own solutions. Then students with different versions work in pairs and compare and discuss their proposals. In the end, paired students share the agreed- 
on version on a class-wide level, and the suitability of the individual proposals is discussed. The nature of the task helps develop sensitivity towards the level of politeness in specific professional settings. The technique itself is beneficial in terms of involvement, cooperation, peer teaching, and development of communication skills.

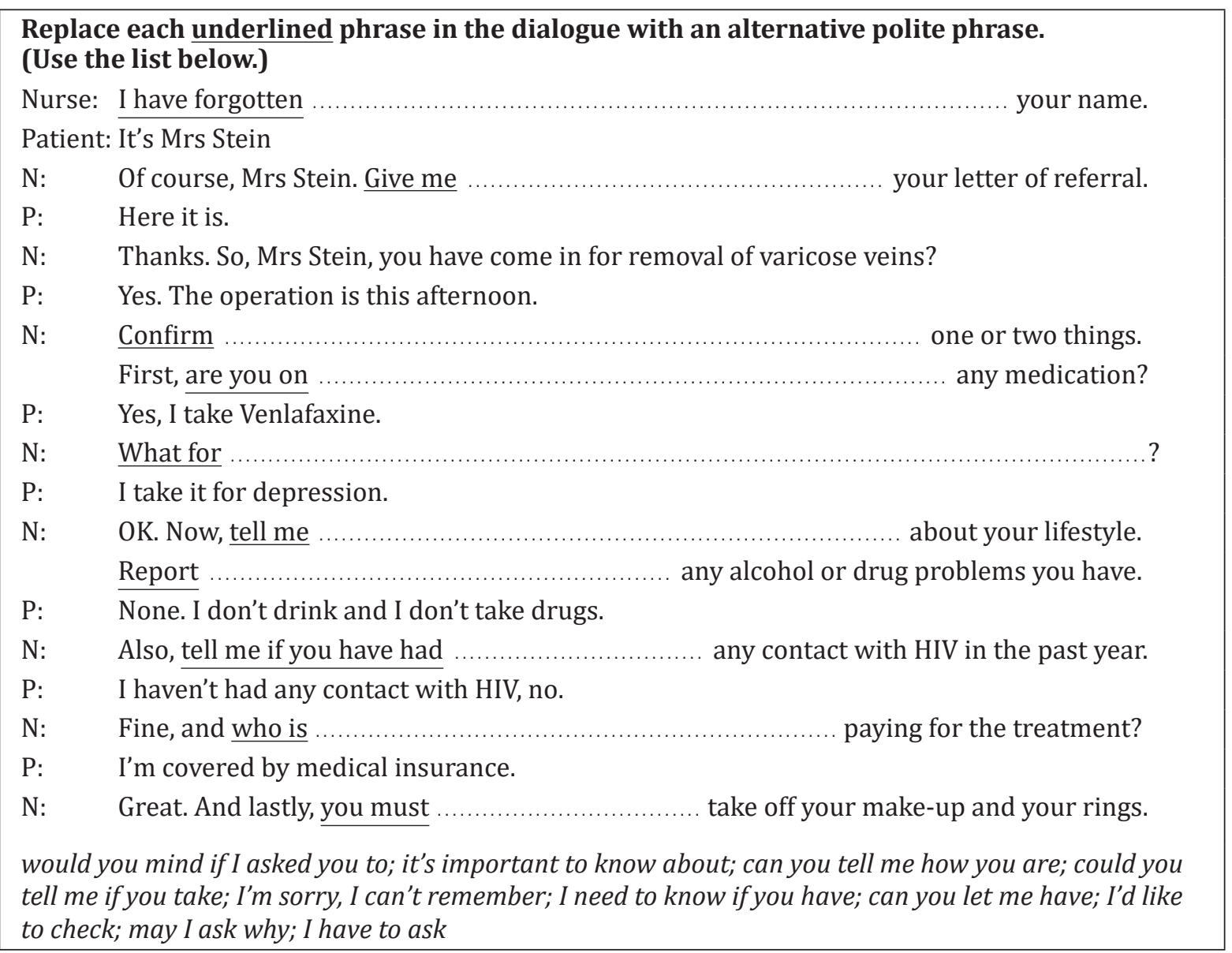

Adapted from: Grice, T. \& Greenan, J. (2008). Nursing 2. Oxford: OUP, 11.

\subsection{Nominating}

According to Prodromou and Clandfield (2007), deliberate nominating (i.e. calling on specific students) is believed to be a relevant tool when dealing with mixedability classes. It is a common occurrence that when a group of students is asked to raise their hands and answer questions, it is usually the stronger and more confident students who do it first. Deliberate nominating enables teachers to more or less equally divide the speaking time and ask more or less demanding questions depending on a student's level of proficiency. Furthermore, when nominated without any specific order (unexpectedly), everyone appears to be more focused on a task. As Prodromou and Clandfield (2007) point out, it is necessary to state a task or ask a question before allocating it to a student. That way, students are 
given time to comprehend and interpret questions and, most importantly, prepare answers. Lastly, mixed-ability classes require a teacher to keep an on-going record of all the students who have already spoken so that the speaking time is distributed evenly. In our experience, nominating helps tailor the task/question to the students' proficiency level and control their speaking time.

\subsection{Other techniques and strategies}

Current teaching methodologies propose a variety of other techniques and strategies used to facilitate the teaching process in mixed-ability classes. To begin with, Scrivener (2012) points out that the same task may be given in a choice of versions. Being probably the most common solution, differentiated worksheets within a group seem to be of crucial importance. That way stronger students are provided with a challenge appropriate for their language level; weaker students, however, are enabled to complete the given task thanks to additional support. The following example of a differentiated worksheet is given by Scrivener (2012, p. 90): "offer an open writing task for stronger students and a similar task for weaker students, but with added support, e.g. guiding questions, a partially written text or a list of ready-made phrases." It needs to be emphasised that when dealing with mixed-ability classes, task variation does not imply that a teacher has to prepare two separate lesson plans. Variety can be offered thanks to a few simple measures, e.g. adding more gaps for stronger students, adding additional supporting questions or visuals for weaker students, providing weaker students with a list of useful phrases, etc. An example of such a differentiated exercise for FZS students is presented below. Version A focuses on vocabulary problems in a context; version B, however, which is allocated to more proficient students, provides the additional challenge of word formation and grammatical problems. 


\section{Version A - Fill in the gaps using the given words: \\ layer / smallest / effects / weight / dangerous / safely / undesirable / prescribe / interact / regimen / drowsiness}

The amount of a drug taken at any one time is called a dose. A minimal dose is the ................. amount that will give the desired effect, while a maximal dose is the largest amount that can be administered Physicians often an average dose - the amount that is effective for most patients. A dose can be expressed as the of the drug, e.g. $400 \mathrm{mg}$, or volume, e.g. $15 \mathrm{ml}$. It can also be a number of items in a dose, like 1 pill or 2 capsules, or some other quantity, e.g. a thin of ointment. The frequency at which the drug is taken is called the drug It means how many times a day a patient has to take the drug and what time period should be between the doses. Patients use their drugs for certain therapeutic effects, but many drugs also have other, effects on the body called side ..................., such as nausea, diarrhoea, dizziness, , rashes, weight gain and others. Doctors also have to take into consideration that any two medications may with each other, either enhancing or suppressing their effects. Combining drugs can also be

\begin{tabular}{|c|}
\hline $\begin{array}{l}\text { Version B - Fill in the gaps using the given words. } \\
\text { The words in bold need to be used in different word forms: }\end{array}$ \\
\hline $\begin{array}{c}\text { layer / small / effects / weight / danger / safe / } \\
\text { undesirable / prescribe / interact / regimen / drowsy }\end{array}$ \\
\hline 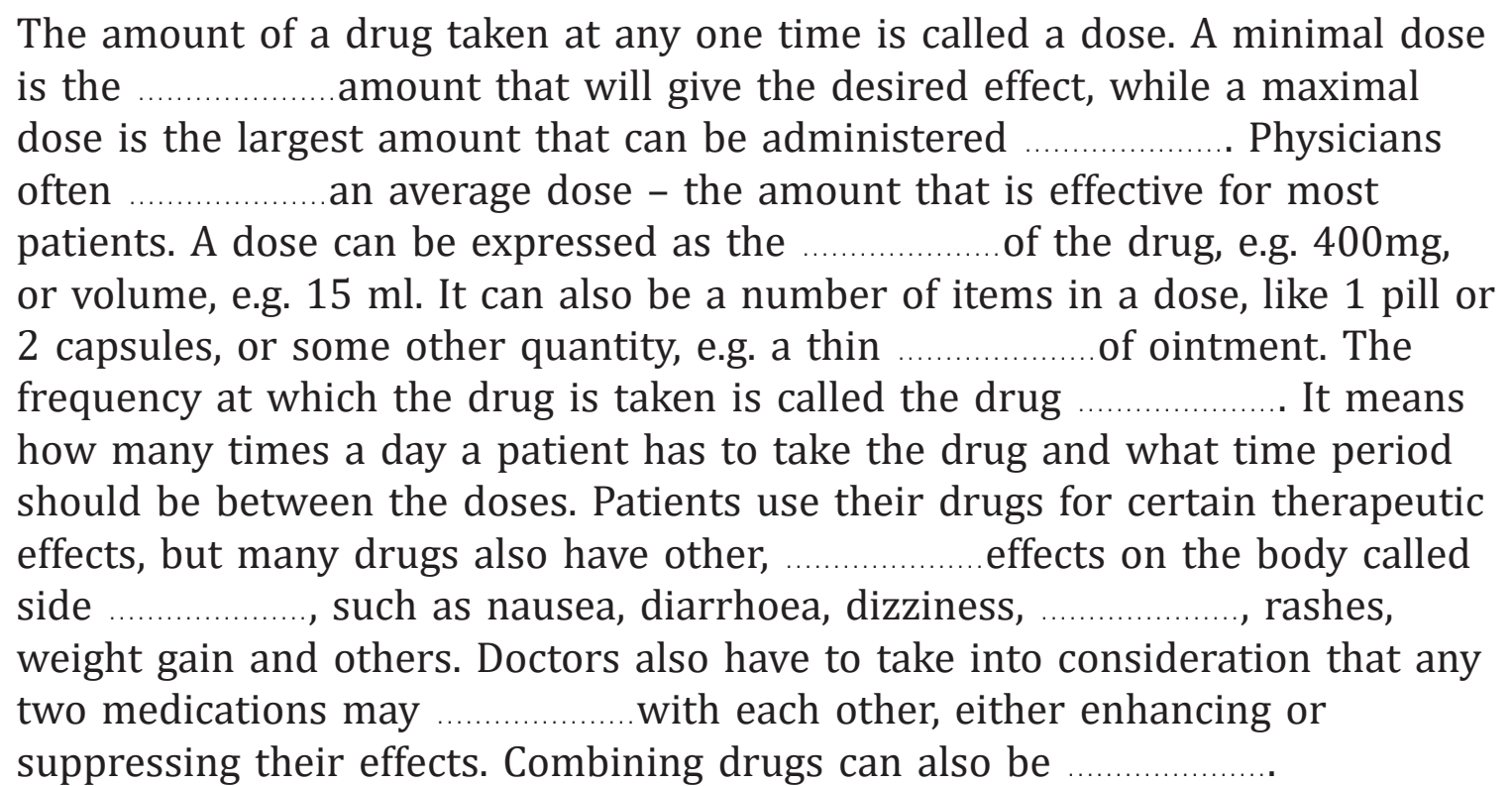 \\
\hline
\end{tabular}

Adapted from: Telínová, A. \& Crossen, G. (2013). English for Medical Professions 2. Plzeň: Západočeská Univerzita v Plzni, 24. 
The common occurrence of high-level students finishing early may cause a problem for many teachers. Ur (2016) suggests that one should prepare a task manageable by all of the students and, additionally, have something that might be undertaken by volunteers. She observes that everyone who fulfils the mandatory exercise succeeds, and students who manage to do more succeed even more. Thus, there is no sense of failure, just a smaller or bigger success. Ur (2016) has also drawn attention to the fact that stronger students may sometimes need reinforcement to work on optional tasks, whereas weaker students might need assurance that it is enough to do mandatory exercises.

Practical implementation of the strategy is illustrated below. The table presents a task that aims at interviewing one's classmates about their eating habits and levels of physical activity. The students walk around the classroom and ask questions to gather information about their classmates. To make sure that everybody is able to fulfil the exercise in time, the students are told that it is required for them to interview a minimum of two people. Therefore, the stronger students have an opportunity to speak more, and the weaker ones can successfully fulfil the mandatory task with no sense of failure.

\begin{tabular}{|l|l|l|l|l|}
\hline & \multicolumn{1}{|c|}{$\begin{array}{c}\text { Classmate } \\
\text { no. 1 }\end{array}$} & $\begin{array}{c}\text { Classmate } \\
\text { no. 2 }\end{array}$ & \multicolumn{1}{c|}{$\begin{array}{c}\text { Classmate } \\
\text { no. 3 }\end{array}$} & \multicolumn{1}{c|}{$\begin{array}{c}\text { Classmate } \\
\text { no. } 4\end{array}$} \\
\cline { 2 - 3 } \cline { 5 - 5 } $\begin{array}{l}\text { What does he/she } \\
\text { typically eat in } \\
\text { a day? }\end{array}$ & & & & \\
\hline $\begin{array}{l}\text { Is he/she active? } \\
\begin{array}{l}\text { What does he/she } \\
\text { do to stay active? }\end{array}\end{array}$ & & & & \\
\hline $\begin{array}{l}\text { What are the } \\
\text { positive and } \\
\text { negative aspects of } \\
\text { his/her diet? }\end{array}$ & & & & \\
\hline $\begin{array}{l}\text { How is his/her } \\
\text { health in general? }\end{array}$ & & & & \\
\hline
\end{tabular}

According to Ur (2016), it is essential to put many open-ended questions, as they facilitate answer variety. When asked an open-ended question, students may use vocabulary and phrases they are familiar with and, therefore, construct sentences adjusted to their own language level. Questions that are closed-ended are often prepared for one specific level of language proficiency. Thus, many students who are in a mixed-ability group may find them either too challenging or too simple.

Another practical example of task variation is illustrated in the "Taking the history" exercise below. After having listened to an admission dialogue, students are asked to practice the questions by asking for personal and medical details 
of their partners and filling them into the form. There are two varieties of the record forms, each available in six versions. The forms are double-sided: one side contains details of a "mock" identity to be assumed by the student; the other side is just an empty form. Students work in pairs, asking their partners for details to complete the empty form with the relevant details. The shorter variety, allocated to weaker students, focuses on practising basic questions needed when taking a patient's history. The longer variety extends the task in terms of both the number and complexity of questions necessary and the level of detail in the answers, thus introducing novel vocabulary items. Students are allowed the same amount of time; the complexity of the second form typically eliminates the occurrence of early finishers. In the final review, each individual student reports the medical condition of his/her partner (every individual condition will be different). A list of the conditions found in all versions is compiled on the board and student pairs are asked to do a "triage", i.e. to decide about the priority of treatment with respect to the level of medical emergency of the individual conditions. Through this activity, weaker students are familiarized with some of new vocabulary, and, at the same time, are prompted to discuss and possibly argue about their priority sequence, thus practising oral fluency.

\begin{tabular}{|l|l|}
\hline Patient Record 1 & \\
\hline First name: & Jennifer \\
\hline Surname & Atkins \\
\hline DOB & 19 October, 1993 \\
\hline Address & 23, Upper Lane, Scarborough \\
\hline Occupation & teacher \\
\hline Marital status & married \\
\hline Next of kin & husband \\
\hline Contact no. & 737 956 347 \\
\hline Smoking intake & doesn't smoke \\
\hline Alcohol intake & occasionally, 20 units (0.2 l) per week \\
\hline Reason for admission & car accident, broken leg and rib \\
\hline Medical history & type 2 diabetes (no insulin) \\
\hline Allergies & no allergies \\
\hline GP & Dr Nicolas Mayer \\
\hline
\end{tabular}




\begin{tabular}{|l|l|}
\hline Patient Record 2 & \\
\hline Name and surname & Ian Scott \\
\hline DOB & 31 August, 1956 \\
\hline Address & 14, Moonlight Crescent, Brighton \\
\hline Occupation & retired, works part-time as an accountant \\
\hline Marital status & married, two children \\
\hline Next of kin & $\begin{array}{l}\text { wife Allison, mobile 605 123 654 } \\
\text { withdrawal }\end{array}$ \\
\hline Alcohol intake & n/a problem with alcohol \\
\hline Smoking intake & shortness of breath \\
\hline Chief complaint: & cough, blood in sputum \\
\hline Additional complaints & exercise, climbing stairs \\
\hline Aggravating factors & sleeping with supported head \\
\hline Relieving factors & Nuradeine (painkiller) occasionally for headache \\
\hline Drug history & hospitalized in 2011 with suspected heart attack \\
\hline Medical history & $\begin{array}{l}\text { breast cancer on mother's side, mother died 2005 } \\
\text { father died 1998 of stroke }\end{array}$ \\
\hline Family history & gluten, special diet \\
\hline Allergies & Dr Fitzwilliam Collins \\
\hline GP & \\
\hline
\end{tabular}

\subsection{Seating arrangement}

In most cases, successful cooperation within a group, especially of mixed-ability, depends greatly on the seating arrangement. Harmer (2007) lists four ways of arranging seats: orderly rows (traditional), and horseshoe, circle or modular arrangements. He claims that orderly rows enable teachers to thoroughly monitor students' work and maintain eye contact with them. Furthermore, this kind of arrangement is regarded as suitable for activities such as grammar explanation, giving presentations, or watching a video. The horseshoe or circle arrangements are often used with smaller groups. Unlike orderly rows, these arrangements particularly enable student-student interaction, learner-teacher equality and class relationships; many teachers consider these factors as important as acquiring knowledge. Finally, the modular arrangement, also called separate tables, is often seen in specialised classes, for instance laboratories. West (2010) states that this type of seating is marked by students sitting in groups around a few tables and a teacher approaching the tables to control, instruct and help the learners. Thanks 
to the modular arrangement, student-student interaction becomes the centre of teachers' attention.

In our experience, variation in seating arrangements is an indispensable tool to achieve good results. It enables teachers to use a greater variety of tasks and activities with students; it also enables teachers to determine what works best for their classes. As discussed above, activity type or level differentiation is unavoidable when teaching mixed-ability classes; thus, the use of a variety of seating arrangements for different kinds of activities helps add an additional level of diversity.

\section{Conclusion}

The intention of this article is to review strategies that have proved themselves to be the most productive in teaching mixed-ability classes, using the example of English language students of the Faculty of Health Care Studies (FZS) at the University of West Bohemia. After characterizing the students of these classes in terms of their initial language competence as reflected in test scores, issues of language aptitude and motivations are discussed. The authors then discuss various teaching strategies and describe their practical implementation in classes, with examples of activities and materials that can be used successfully with mixedability groups.

Some of the strategies presented will require rather sophisticated preparation on the part of the teacher; moreover, once in place, the teacher needs to be sensitive towards the unique atmosphere in the class group when using a particular technique. Students' competence, aptitude, motivation, and other characterises are not fixed; they alter over time. Despite the limitations of time and group size, teachers must assess the different levels present in a mixed-ability class and adopt and adjust materials, tasks and expectations in order to, as much as possible, positively influence the learning outcomes for all individual students. Even though one may assume that working with mixed-ability groups is demanding, time-consuming and sometimes frustrating, it might also be seen as a challenge and a rewarding experience for a teacher.

In mixed-ability classes, comparing one's own results with those of fellow students comes naturally. The role of a teacher is to serve as a guide, to explain that a starting point may be set differently for individual students, but they all have the same opportunity to move up. Having said that, we must then be willing to put in the effort required to adopt our teaching activities as much as possible to the different levels present in our classes. Then, if the learning process takes place in a friendly atmosphere, is interesting, varied, and enjoyable, all students will thrive. The ultimate aim of a good teacher is that all students have an opportunity 
to experience solidly-grounded success. What remains a question to be answered by further research are the reasons why students who went through more or less the same or very similar language programmes in their elementary and secondary schools demonstrate such great differences in their language competence when they reach the university. It may be challenging to teach mixed-ability classes, but, within the educational system, we need to ask what produces these inequalities.

\section{Resources}

GolemAn, D. (2005) Emotional intelligence. New York: Bantam Dell, 33-45, 79-95.

Grice, T. \& GREENAN, J. (2008). Nursing 2. Oxford: OUP, 11.

DöRNYEI, Z. (2001) Motivational strategies in the language classroom. Cambridge: Cambridge University Press, 40-46.

Findley, J. H., \& Cooper, H. M. (1993) Locus of control and academic achievement: a literature review. Journal of Personality and Social Psychology, 44(2), 419-27, in Williams, M. \& Burden, R. L. (1997).

HARMER, J. (2015). The practice of English language teaching. Harlow: Pearson Education Limited, 86-94, 177-180.

Lightbown, P. \& Spada, N. (2013) How languages are learnt. Oxford: Oxford University Press, 77-92.

MCKeACHIE, W. J. $(1951,1999)$ McKeachie's teaching tips. Belmont, CA: Wadsworth, Cengage Learning, in Weimer, M. (2008) Four teaching maxims that endure. Available at https://www.facultyfocus.com/ articles/philosophy-of-teaching-four-teaching-maxims-that-endure/

UR, P. (2016). Penny Ur's 100 Teaching Tips. Cambridge: Cambridge University Press, 48-50.

UR, P. (2012). A Course in English language teaching. Cambridge: Cambridge University Press, 54-55, 272282.

Prodromou, L. \& Clandfield, L. (2007). Dealing with difficulties. Solutions, strategies and suggestions for successful teaching. Peaslake: Delta Publishing, 57-87.

SCRIVEnER, J. (2012). Classroom management techniques. Cambridge: Cambridge University Press, 88-96, 199-223.

Seymour, D. \& Popova, M. (2005) 700 classroom activities. London: Macmillan Education, 107

Sieglová, D. (2019) Konec školní nudy. Praha: Grada Publishing, 62-63

Telínová, A. \& CRossen, G. (2013). English for medical professions 2. Plzeň: Západočeská Univerzita v Plzni, 11

WENDEN, A, \& RuBin, J. (1987) Learner strategies in language learning. London: Prentice Hall International, 23-29.

WEST, K. (2010). Inspired English teaching. A practical guide for teachers. New York: Continuum International Publishing Group, 16-17.

Williams, M. \& BURDEN, R. L. (1997) Psychology for language teachers. Cambridge: Cambridge University Press, 65-78, 101-103, 121-127. 


\section{Authors}

Mgr. Marie Majerová, e-mail: mamajer@ujp.zcu.cz, University of West Bohemia, Institute of Applied Language Studies.

She is an ESP instructor with extensive teaching experience in the Faculty of Health Care Studies (FZS) at UWB; as the guarantor of the FZS English courses, she designs curricula and participates in the production of teaching and testing materials.

Mgr. Bartłomiej Wróbłewski, e-mail: bwroblew@ujp.zcu.cz, University of West Bohemia, Institute of Applied Language Studies

He graduated from Kazimierz Wielki University in Bydgoszcz, Poland. He works as an ESP lecturer focusing mainly on Medical English and English for Mechanical Engineering. His main research interest is teaching methodology. 